\title{
Hydrodynamics and measurement of natural currents in a plain river using acoustic Doppler equipment
}

\section{Hidrodinámica y medición de corrientes naturales en un río de planicie utilizando equipos acústicos Doppler}

\author{
Gastón Priego-Hernández ${ }^{1}$, Héctor Rubio-Arias² ${ }^{2}$ Fabián Rivera-Trejo ${ }^{3 *}$ \\ ${ }^{1}$ División Académica de Ciencias Básicas, Universidad Juárez Autónoma de Tabasco. Carretera Cunduacán-Jalpa Km. 1 Col. \\ La Esmeralda CP. 86690. Cunduacán, Tabasco, México. \\ ${ }^{2}$ Departamento de Recursos Naturales, Facultad de Zootecnia y Ecología. Universidad Autónoma de Chihuahua. Periferico \\ Francisco R. Almada Km. 1. CP. 33820. Chihuahua, México. \\ ${ }^{3}$ División Académica de Ingeniería y Arquitectura, Universidad Juárez Autónoma de Tabasco. Carretera Cunduacán-Jalpa Km. \\ 1 Col. La Esmeralda CP. 86690. Cunduacán, Tabasco, México. \\ *Corresponding author: jgfabianrivera @gmail.com
}

Scientific article received: June 22, 2017 accepted: February 12, 2018

\begin{abstract}
Flow discharge and hydrodynamic field measurements are essential data for understanding aquatic ecosystems. The objective of this study was to compare the use of three Acoustic Doppler Current Profilers (ADCPs) in measuring flow discharge and hydrodynamics in the Carrizal River located in southeastern Mexico. The evaluated ADCPs operate on frequencies of $2000 \mathrm{kHz}, 1500 \mathrm{kHz}$ and $600 \mathrm{kHz}$. The measurements were carried out in a 100-m-wide cross section, five times each for each ADCP, within an estimated time of $5 \mathrm{~min}$. The obtained data were: 1) flow velocity components; 2) depth; 3) transversal distance between each vector; 4) total distance of the cross section and; 5) geographic position of each vector. Tecplot ${ }^{\circledR}$ graphics were made with the collected information. The results showed that velocity magnitudes were low in bank areas, while high in the center. For a 5-m depth range, the $2000-\mathrm{kHz}$ ADCP keeps a more homogenous velocity distribution in comparison with the other equipment. The results showed that discharge measurements varied by no more than $5 \%$ among ADCPs. It is concluded that the most important variable in choosing an ADCP for a hydrodynamic study is its operating frequency.
\end{abstract}

Key words: Doppler equipment, operating frequency, hydrodynamics, flow discharge

RESUMEN. El aforo de corrientes y el mapeo de campos de velocidad, es información esencial para el entendimiento de los ecosistemas acuáticos. El objetivo del estudio fue comparar tres perfiladores acústicos Doppler, también conocidos como ADCP (Acoustic Doppler Current Profiler), en el río Carrizal localizado en el Sureste mexicano. Los equipos ADCP evaluados operan en frecuencias de $2000 \mathrm{kHz}, 1500 \mathrm{kHz}$ y $600 \mathrm{kHz}$. La medición se efectuó en una sección transversal de $100 \mathrm{~m}$ de ancho, realizando cinco recorridos con cada equipo con una duración aproximada de $5 \mathrm{~min}$. Se registró información de: 1) componentes de velocidad del flujo, 2) profundidad, 3) distancia transversal entre cada vector, 4) distancia total de la sección transversal y 5) posición geográfica de cada vector. Con la información obtenida se elaboraron gráficas en Tecplot $\AA$. Los resultados muestran que las magnitudes de velocidad fueron bajas en la zona de márgenes, mientras que las altas en el centro de la sección. Para un rango de profundidad de $5 \mathrm{~m}$, el ADCP de 2 $000 \mathrm{kHz}$ tuvo una distribución de velocidad más detallada al compararla con los otros dos equipos. Los gastos medidos con cada equipo no variaron en más de un $5 \%$. La generación del campo de velocidades, es la variable más importante al seleccionar un ADCP es su frecuencia de operación.

Palabras clave: Equipo Doppler, frecuencia de operación, hidrodinámica, aforo líquido 


\section{INTRODUCTION}

Flow discharge and hydrodynamic measurements of any aquatic system allow us to know that habitat and, at the same time, analyze how it can be altered from an environmental point of view. Currently, these variables are measured using acoustic Doppler equipments, also known as acoustic Doppler current profilers (ADCPs) (Winterwerp et al. 2006). ADCPs have become popular due to their efficiency, speed and quality in flow measurement (Szupiany et al. 2007, Priego-Hernández and Rivera-Trejo 2016). They use frequencies greater than $25 \mathrm{kHz}$, which allows them to quantify the vibration of particles suspended in water. At a low frequency, the amplitude of vibration is equal to that of the medium, but the increase augments the effect of the inertia of the particles. At frequencies greater than $25 \mathrm{kHz}$, the vibration remains stationary, allowing the flow velocity to be measured (Vogt and Neubauer 1976). The ADCPs, depending on their configuration, work at high or low frequencies, and even with the combination of the two; this determines the range, penetration and number of cells (discretization) of the acoustic pulse in the water column. Another feature of ADCPs is their difficulty in measuring velocities close to the bottom of the channel (Simpson 2001), which translates into error (Fulford and Sauer 1986).

The measurement error of velocities measured with an ADCP is of the order of $\pm \mathrm{cm}^{-1}$. In measuring the flow of a river with different ADCP configurations, Mueller (2002) found that they had a difference of the order of $\pm 5 \%$. Currently, ADCPs are used for the quantification of sediment transport (Venditti et al., 2016), detection of secondary currents (Priego-Hernández and Rivera-Trejo 2016), monitoring of wetlands (Arega 2013), understanding fluvial habitats (Cundy et al. 2007), knowledge of aquatic ecosystems (Chang et al., 2015) and calibration of numerical models (García-Reyes et al. 2017).

For all the aforementioned reasons, it is important to select the ideal or most suitable equip- ment. However, it is common to find equipment that has different configurations (operating frequencies), which measure the same depth range. Given this situation, there is uncertainty about the type and quality of data obtained with each device. Therefore, the aim of the study was to compare the use of three acoustic Doppler current profilers that operate at different frequencies $(2000 \mathrm{kHz}$, $1500 \mathrm{kHz}$ and $600 \mathrm{kHz}$ ) in the Carrizal River and determine the most suitable equipment.

\section{MATERIALS AND METHODS}

The study was carried out in the flood season in a section of the Carrizal River, located near the capital of the state of Tabasco, Mexico (Figure 1 ), in zone $15 \mathrm{~N}$ of the Grijalva hydrological region, Usumacinta (RH-30), Grijalva subbasin, Villahermosa ( $\mathrm{RH}-30 \mathrm{Dv})$. The river is one of the most important in Southeast Mexico; the selected section has a low sinuosity (sinuosity $=1.27$ ), no obstacles and constant area. The flow regime is classified as subcritical (plain river), with an average slope of 0.0003 measured from the El Macayo gate to the Grijalva-Carrizal confluence. It has an average annual flow rate of $350 \mathrm{~m}^{3} \mathrm{~s}^{-1}$, with a maximum annual flow rate of $1466 \mathrm{~m}^{3} \mathrm{~s}^{-1}$ (Rivera et al. 2010).

Three acoustic Doppler current profilers ( $\mathrm{Ta}$ ble 1) that work at the following frequencies were used: 1) $2000 \mathrm{kHz}$, 2) $1500 \mathrm{kHz}$, and 3) $600 \mathrm{kHz}$. Measurements were made in an approximately $100-$ m-wide cross section; five trips or measurements were made with each of the ADCPs mounted on a motorboat. Each trip took approximately $5 \mathrm{~min}$, starting from the left riverbank and going to the right one as suggested by Pérez and Díaz (2000). The size configurations of the ADCP measurement cell were $0.20 \mathrm{~m}$ for the $2000-\mathrm{kHz}$ ADCP and 0.50 $\mathrm{m}$ for the $1500-\mathrm{kHz}$ one, whereas the $600-\mathrm{kHz}$ ADCP was auto-configured every $0.10 \mathrm{~m}$ in the first five cells and $0.40 \mathrm{~m}$ in the remaining cells until reaching the total measurement depth, which was of the order of $5 \mathrm{~m}$. The data obtained with the 

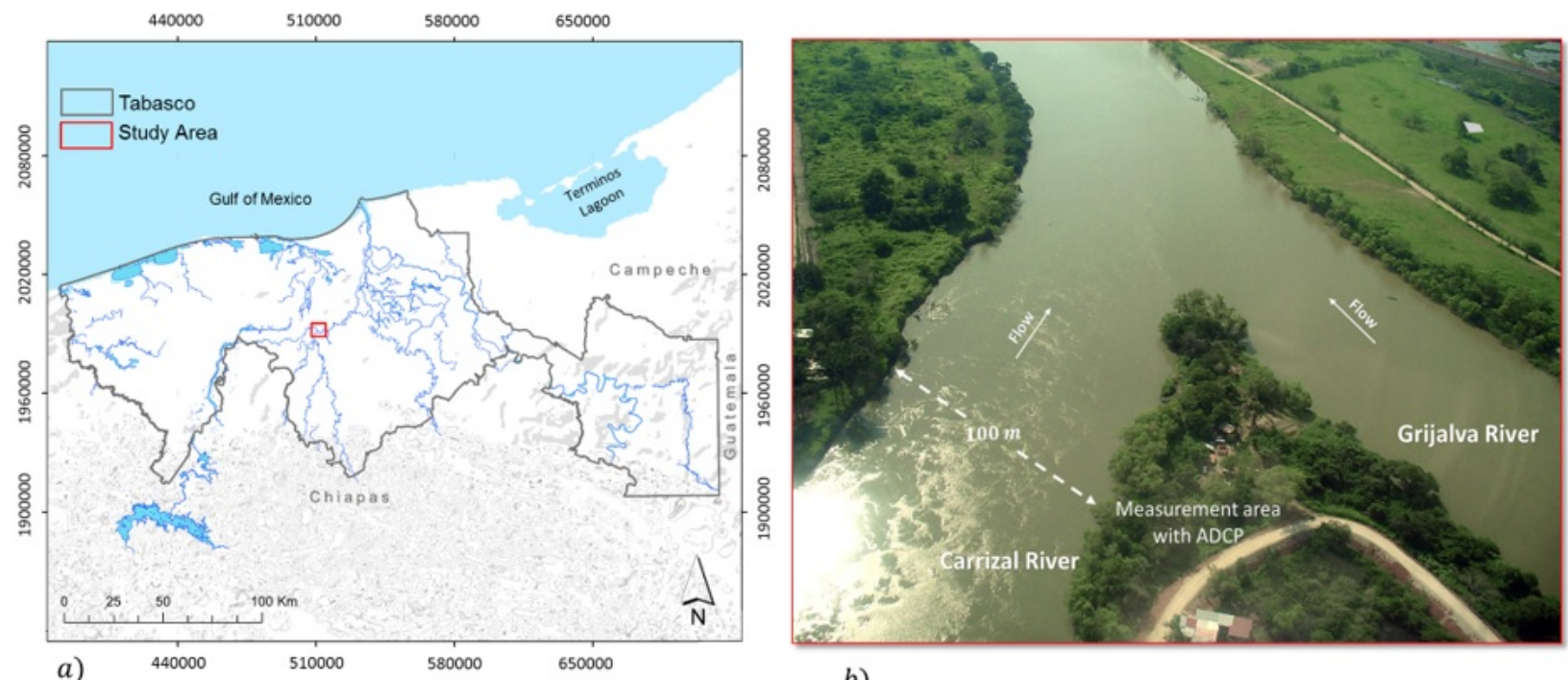

b)

Figure 1. a) Location of the Carrizal River in the state of Tabasco, Mexico b) Measurement point in the Carrizal River.

Table 1. Characteristics and configuration of the acoustic equipment used.

\begin{tabular}{llll}
\hline Specifications & StreamPro (Teledyne) & RiverCat (Sontek) & RiverRay (Teledyne) \\
\hline Frequency & $2000 \mathrm{kHz}$ & $1500 \mathrm{kHz}$ & $600 \mathrm{kHz}$ \\
Beam angle & $20^{\circ}$ & $25^{\circ}$ & $30^{\circ}$ \\
Operation range & $0.20-7.0 \mathrm{~m}$ & $0.90-30 \mathrm{~m}$ & $0.40-60 \mathrm{~m}$ \\
Cell size & $0.02-0.20 \mathrm{~m}$ & $0.25-4.0 \mathrm{~m}$ & Automatic selection* \\
Blanking & $0.03 \mathrm{~m}$ & $0.40 \mathrm{~m}$ & 0.25 \\
\hline
\end{tabular}

three ADCPs in the cross section were captured with the equipment's operating software (River Surveyor ${ }^{\circledR}$ or Winriver $1{ }^{\circledR}$ ). With the data, a spreadsheet was generated in Excel ${ }^{\circledR}$ to perform the filtering to classify the data according to: 1) flow velocity components, 2) measurement depth of each vector, 3) measured transversal distance between each vector, 4) total distance of the cross section and 5) geographical position of each velocity vector. Then the velocity field graphics were constructed with the Tecplot ${ }^{\circledR}$ software.

\section{Equipment calibration}

It is essential that the velocity vectors be measured in the correct direction, so the internal compass of each equipment must be calibrated before the measurements, a process known as Heading, Pitch and Roll (HPR). The calibration for the 2000
$\mathrm{kHz}$ and $600-\mathrm{kHz}$ ADCPs was made with circular movements on their horizontal plane in the clockwise direction, while in the $1500-\mathrm{kHz}$ equipment the circular movements were made on the vertical plane. Magnetic declination is a variable that must be supplied to the equipment, depends on the coordinates of the study site, and is calculated as the angular difference between the magnetic North Pole and the geographic North Pole. The magnetic declination was obtained from the British Geological Survey webpage (BGS 2015). Another parameter to be taken into account is the mobility of the river bottom, which was determined by leaving the vessel stationary and then measuring it with each ADCP for $5 \mathrm{~min}$. This is because the ADCPs detect whether the bottom is mobile, and, if so, the software corrects the measurements automatically. 


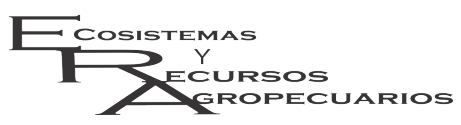

Hydrodynamics and discharge with Doppler equipment

Ecosist. Recur. Agropec.

5(14):293-301,2018
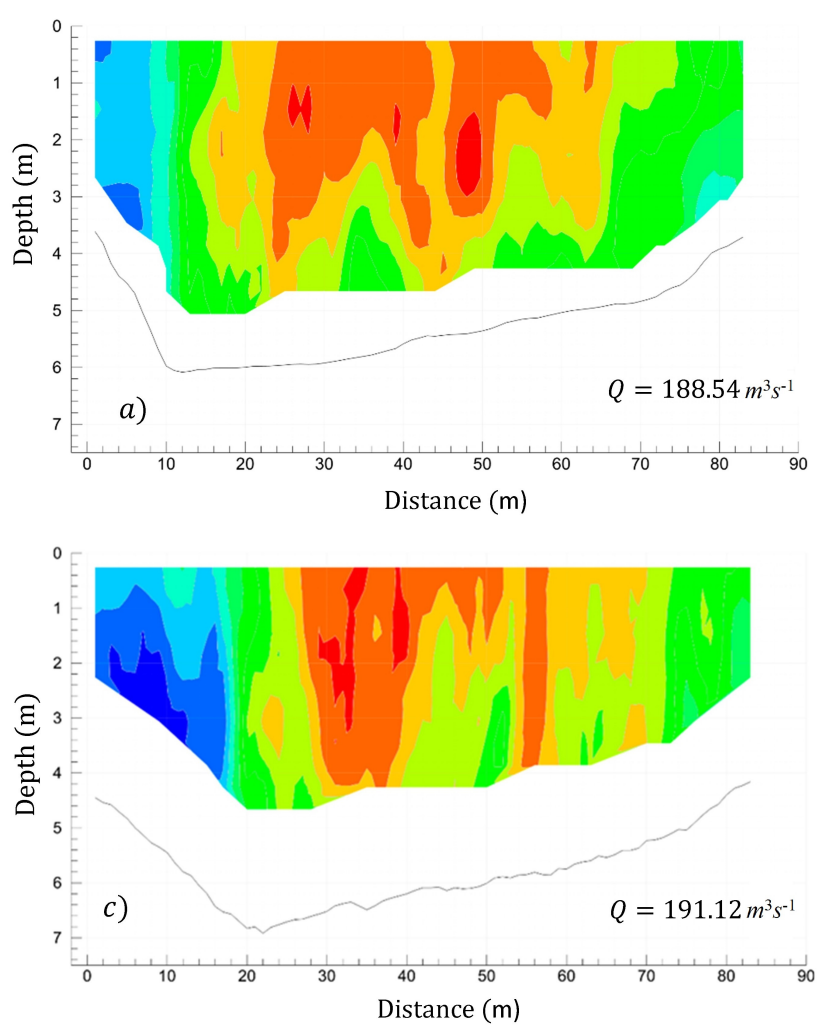
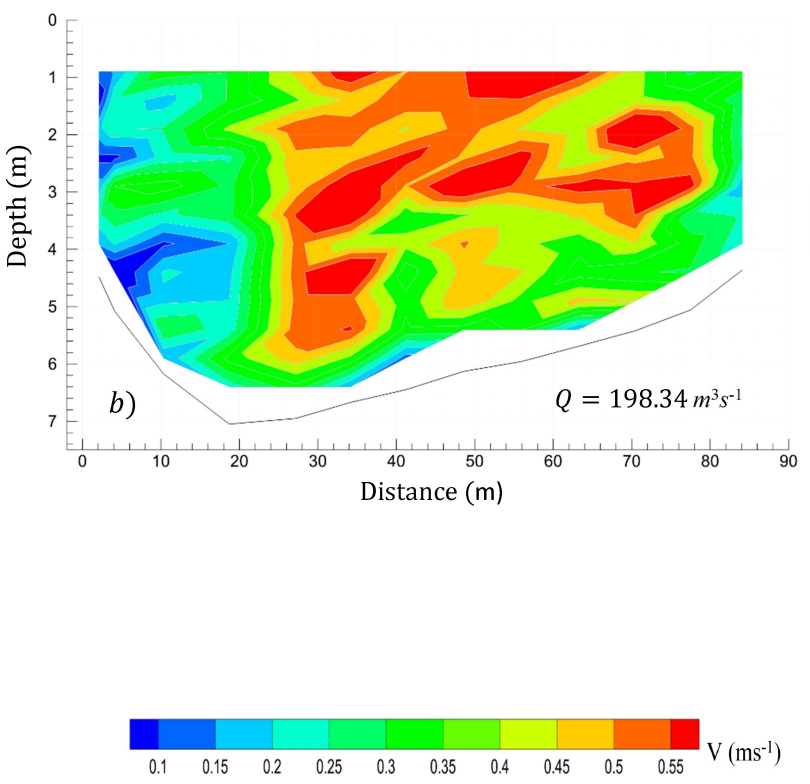

Figure 2. Magnitude of the velocity vectors in the cross section: a) $2000 \mathrm{kHz}$; b) $1500 \mathrm{kHz}$; ). $600 \mathrm{kHz}$.

\section{RESULTS}

\section{Velocity fields and planform maps of velocity vectors}

Figure 2 shows the magnitudes of the velocity fields measured in the cross section, with each of the acoustic profilers. It can be seen that the smaller magnitudes, in blue, are at the banks, while the larger magnitudes, in red, are located in the center of the section. One can also see the size of the blanking zones, without measurement, where the velocities of the bed near the channel and the banks cannot be quantified with the ADCPs. In Figure $3 a-c$, the planform maps of velocity vectors of each ADCP are plotted, showing the flow path or current lines, measured in the cross section under study. These results can be combined to superimpose other phenomena, such as sediment transport or pollutant dispersal. Also in Figure 3d the comparison between the planform maps of velocity vectors measured with each ADCP is observed. It can be observed that the $1500-\mathrm{kHz}$ ADCP presented deviation in its path, due to the direction the vessel followed. Therefore, repeating the measurement at least five times is recommended, since comparisons are made with the average value.

In Figure 4 it can be seen that for a depth of up to $5 \mathrm{~m}$, the $2000-\mathrm{kHz}$ ADCP has a more detailed velocity distribution, arrows closer together, compared to the other two devices. This same Figure also shows that the $1500-\mathrm{kHz}$ ADCP has greater spacing between the velocity vectors and a blanking zone of approximately $0.90 \mathrm{~m}$. It can also be seen that the $600-\mathrm{kHz}$ ADCP has greater detail in the first $0.50 \mathrm{~m}$, because the size of its cells is smaller; however, after that depth the size grows and the vectors also have greater separation.

Table 2 shows the average values of the velo- 

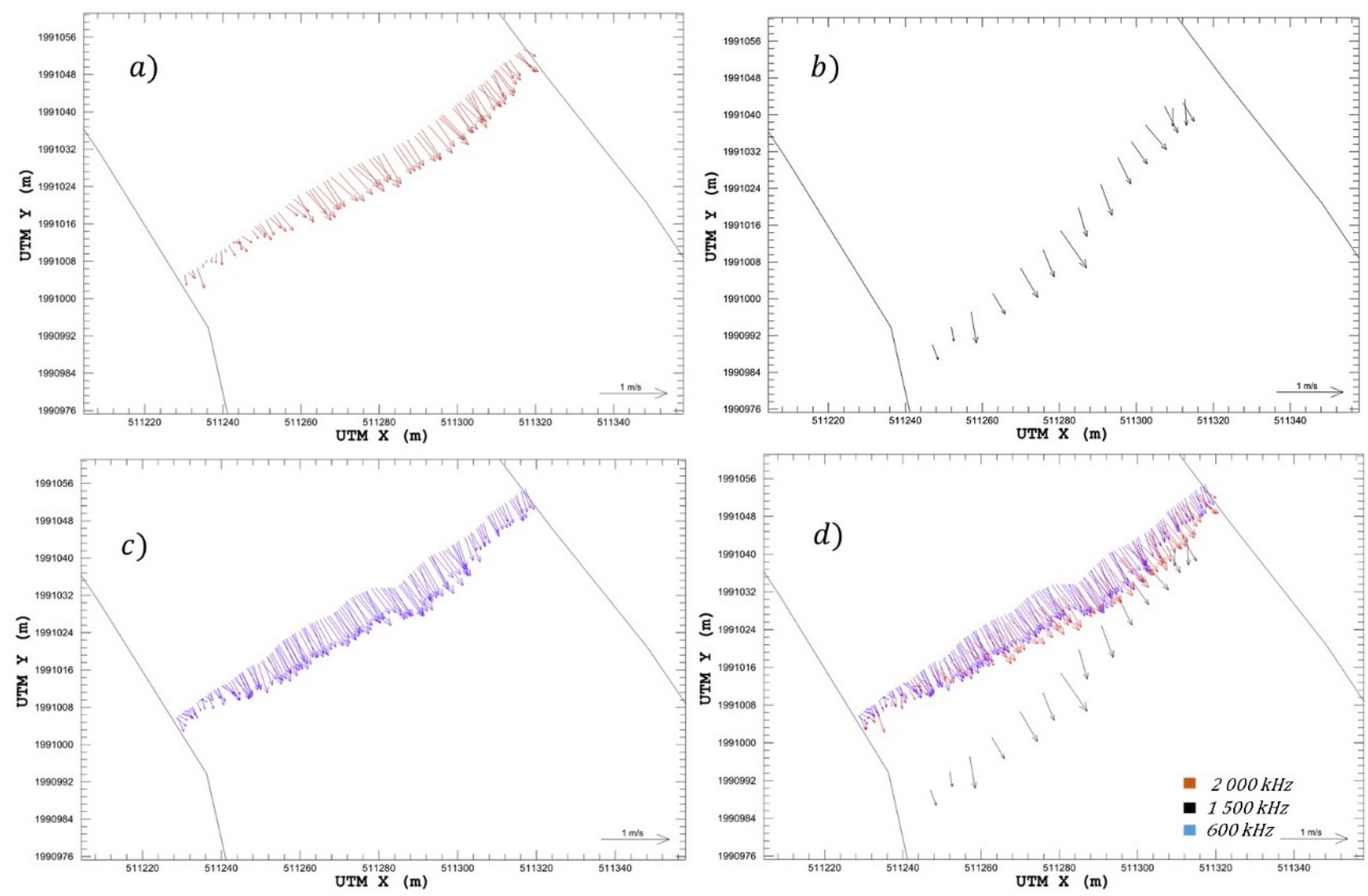

Figure 3. Planform maps of velocity vectors a) $2000 \mathrm{kHz}$; b) $1500 \mathrm{kHz}$; ) $600 \mathrm{kHz}$ and d) comparison.

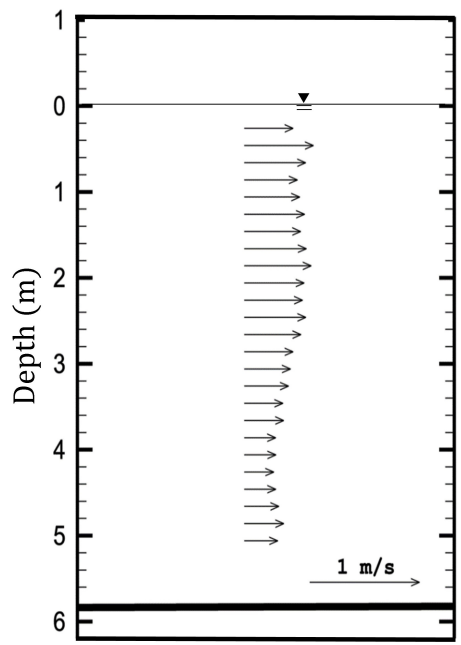

a) $2000 \mathrm{kHz}$

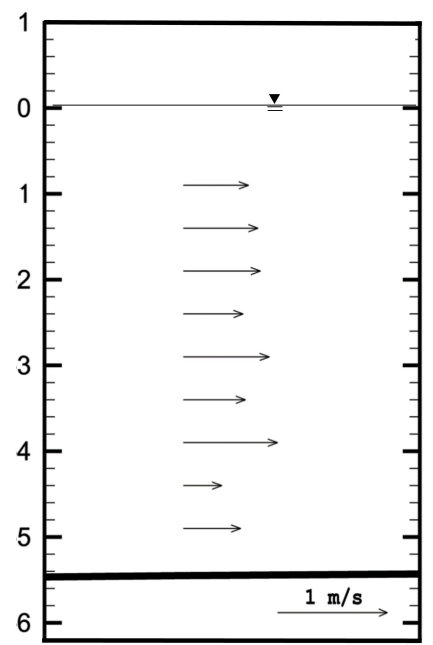

b) $1500 \mathrm{kHz}$

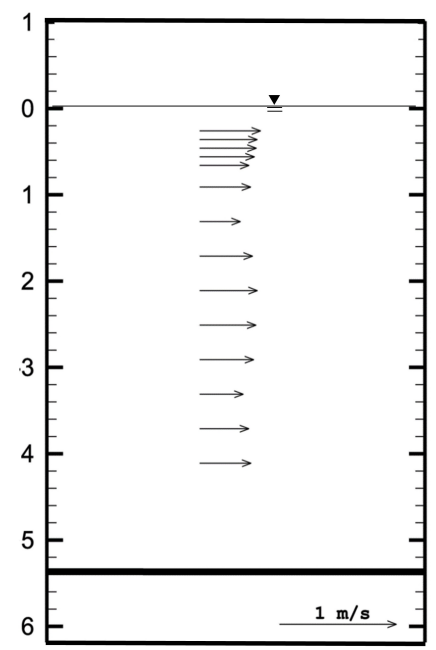

c) $600 \mathrm{kHz}$

Figure 4. Distribution of velocity profiles. 
city magnitude in the water column of the cross section studied. The separation between the measurement depths of each device, which is a function of the cell size used, can be seen. Table 3 presents the flow measured with each ADCP in the cross section. The standard deviation associated with the flows obtained with the $2000-\mathrm{kHz}$ ADCP shows a small variation, when compared with the flow rates obtained with the $1500-\mathrm{kHz}$ ADCP, which has a higher standard deviation. Table 4 shows that the highest number of cells per unit area was obtained by the $2000-\mathrm{kHz}$ ADCP, which is explained by the equipment's cell size of $0.20 \mathrm{~m}$ and measuring time of $1.40 \mathrm{~s}$. When comparing it to the $0.50 \mathrm{~m}$ cell size of the $1500-\mathrm{kHz}$ ADCP, it has a smaller number of cells per unit area with an equipment set time of $4.57 \mathrm{~s}$, which implies that the transducer software will seek to interpolate the data where the ADCP cannot measure, which increases measurement error.

Table 2. Number of cells and velocity magnitude at points in the water column.

\begin{tabular}{|c|c|c|c|c|c|}
\hline \multicolumn{2}{|c|}{$2000 \mathrm{kHz}$} & \multicolumn{2}{|c|}{$1500 \mathrm{kHz}$} & \multicolumn{2}{|c|}{$600 \mathrm{kHz}$} \\
\hline$h(m)$ & $|\vec{v}|\left(\mathrm{ms}^{-1}\right)$ & $h(m)$ & $|\vec{v}|\left(\mathrm{ms}^{-} 1\right)$ & $h(m)$ & $|\vec{v}|\left(\mathrm{ms}^{-} 1\right)$ \\
\hline 0.26 & 0.5750 & - & - & 0.26 & 0.5228 \\
\hline 0.46 & 0.6489 & - & - & 0.36 & 0.5140 \\
\hline 0.66 & 0.5766 & - & - & 0.46 & 0.5162 \\
\hline 0.86 & 0.6582 & 0.9 & 0.5870 & 0.56 & 0.4453 \\
\hline 1.06 & 0.7242 & - & - & 0.66 & 0.4461 \\
\hline 1.26 & 0.5279 & - & - & 0.91 & 0.4212 \\
\hline 1.46 & 0.6430 & 1.4 & 0.6285 & 1.31 & 0.3810 \\
\hline 1.66 & 0.5622 & - & - & - & - \\
\hline 1.86 & 0.6149 & 1.9 & 0.6989 & 1.71 & 0.5562 \\
\hline 2.06 & 0.5393 & - & - & - & - \\
\hline 2.26 & 0.4769 & - & - & 2.11 & 0.5344 \\
\hline 2.46 & 0.4587 & 2.4 & 0.6408 & - & - \\
\hline 2.66 & 0.4523 & - & - & 2.51 & 0.4431 \\
\hline 2.86 & 0.5268 & - & - & - & - \\
\hline 3.06 & 0.3979 & 2.9 & 0.4823 & 2.91 & 0.5621 \\
\hline 3.26 & 0.3883 & - & - & - & - \\
\hline 3.46 & 0.4428 & 3.4 & 0.4572 & 3.31 & 0.5041 \\
\hline 3.66 & 0.4187 & - & - & - & - \\
\hline 3.86 & 0.4699 & 3.9 & 0.5123 & 3.71 & 0.5358 \\
\hline 4.06 & 0.4254 & - & - & - & - \\
\hline 4.26 & 0.4212 & - & - & 4.11 & 0.3430 \\
\hline 4.46 & 0.4291 & 4.4 & 0.6277 & - & - \\
\hline 4.66 & 0.3622 & - & - & - & - \\
\hline & & 4.9 & 0.3771 & - & - \\
\hline
\end{tabular}

h, measurement depth; $|\vec{v}|$, magnitude of the velocity vector.

\section{DISCUSSION}

Table 3 shows that the $1500-\mathrm{kHz}$ ADCP had the highest uncertainty, approximately $5 \%$, which coincides with Mueller (2002), while the 2000 $\mathrm{kHz}$ ADCP had the least uncertainty. The flow velocity magnitude results obtained by the three ADCPs (Figure 2) differ in the distribution of the color range, because it corresponds to field measurements. The three ADCPs showed that the highest velocities are in the center of the river's cross section. This is a common finding in the cross section of a straight stretch of river with no obstacles, and these velocities coincide with what was found in previous studies (Baranya et al. 2015, Riley and Rhoads 2011). In the case of velocity profiles (Figure 5), the best distribution was with the $2000-\mathrm{kHz}$ ADCP, the values of which are more discretized or with a greater number of cells, in the vertical and horizontal scales. These results contrast with those obtained with the 1500 $\mathrm{kHz}$ and $600-\mathrm{kHz}$ ADCPs, which despite having a greater and smaller number of measurement points respectively, the distribution of their velocity profiles does not improve the quality. Regarding Szupiany et al. (2009) and Baranya et al. (2015), they indicate that a more uniform distribution in the velocity profiles allows for a detailed visualization of the transversal or secondary velocities. In addition, based on the velocity profiles, tangential stresses on the river bottom and Manning's roughness coefficients are determined and related to the suspension and bed load sediment transport. In this regard, in the present study, the best distribution was with the $2000-\mathrm{kHz}$ ADCP. Regarding Szupiany et al. (2009) y Latosinski et al. (2014), they developed several methodologies to estimate suspended sediment transport from measurements with Doppler equipment, without reporting difficulties or limitations of the equipment. This work corroborates the results of Muller et al. (2009), who indicate that high turbulence and high bed sediment transport cause measurement problems in the ADCP. This is more noticeable in high-frequency 
Table 3. Average flow rate in the cross section under study.

\begin{tabular}{|c|c|c|c|c|c|c|c|c|}
\hline$Q,\left(m^{3} s^{-} 1\right)$ & $\begin{array}{r}2000 \mathrm{kHz} \\
\hat{Q},\left(m^{3} s^{-} 1\right)\end{array}$ & $\hat{Q}_{\sigma}\left(m^{3} s^{-} 1\right)$ & $Q,\left(m^{3} s^{-} 1\right)$ & $\begin{array}{l}1500 \mathrm{kHz} \\
\hat{Q},\left(m^{3} s^{-} 1\right)\end{array}$ & $\hat{Q}_{\sigma}\left(m^{3} s^{-} 1\right)$ & $Q,\left(m^{3} s^{-} 1\right)$ & $\begin{array}{c}600 \mathrm{kHz} \\
\hat{Q},\left(m^{3} s^{-} 1\right)\end{array}$ & $\hat{Q}_{\sigma}\left(m^{3} s^{-} 1\right)$ \\
\hline 189.17 & & & 204.73 & & & 188.84 & & \\
\hline 188.54 & & & 192.4 & & & 198.46 & & \\
\hline 189.77 & 189.15 & 0.497 & 191.61 & 197.20 & 4.80 & 187.73 & 191.85 & 3.79 \\
\hline 188.66 & & & 198.93 & & & 193.11 & & \\
\hline 189.64 & & & 198.34 & & & 191.11 & & \\
\hline
\end{tabular}

Table 4. Comparison of the discharge obtained in the cross section under study, with the different devices.

\begin{tabular}{lllllll}
\hline ADCP & $C S(m)$ & $\hat{B}(m)$ & $\hat{A}\left(m^{2}\right)$ & $\hat{C}$ & $\hat{V}\left(m s^{-} 1\right)$ & $\hat{Q},\left(m^{3} s^{-} 1\right)$ \\
\hline $2000 \mathrm{kHz}$ & 0.20 & 97.66 & 528.49 & 2045.44 & 0.357 & 189.15 \\
$1500 \mathrm{kHz}$ & 0.50 & 89.04 & 488.05 & 166.62 & 0.402 & 197.20 \\
$600 \mathrm{kHz}$ & 0.40 & 92.86 & 503.17 & 1663.45 & 0.382 & 191.85 \\
\hline
\end{tabular}

$C S$, cell size; $\hat{B}$, average width; $\hat{A}$, average area; $\hat{C}$, average number of cells per section; $\hat{V}$, average velocity; $\hat{Q}$, average flow rate.
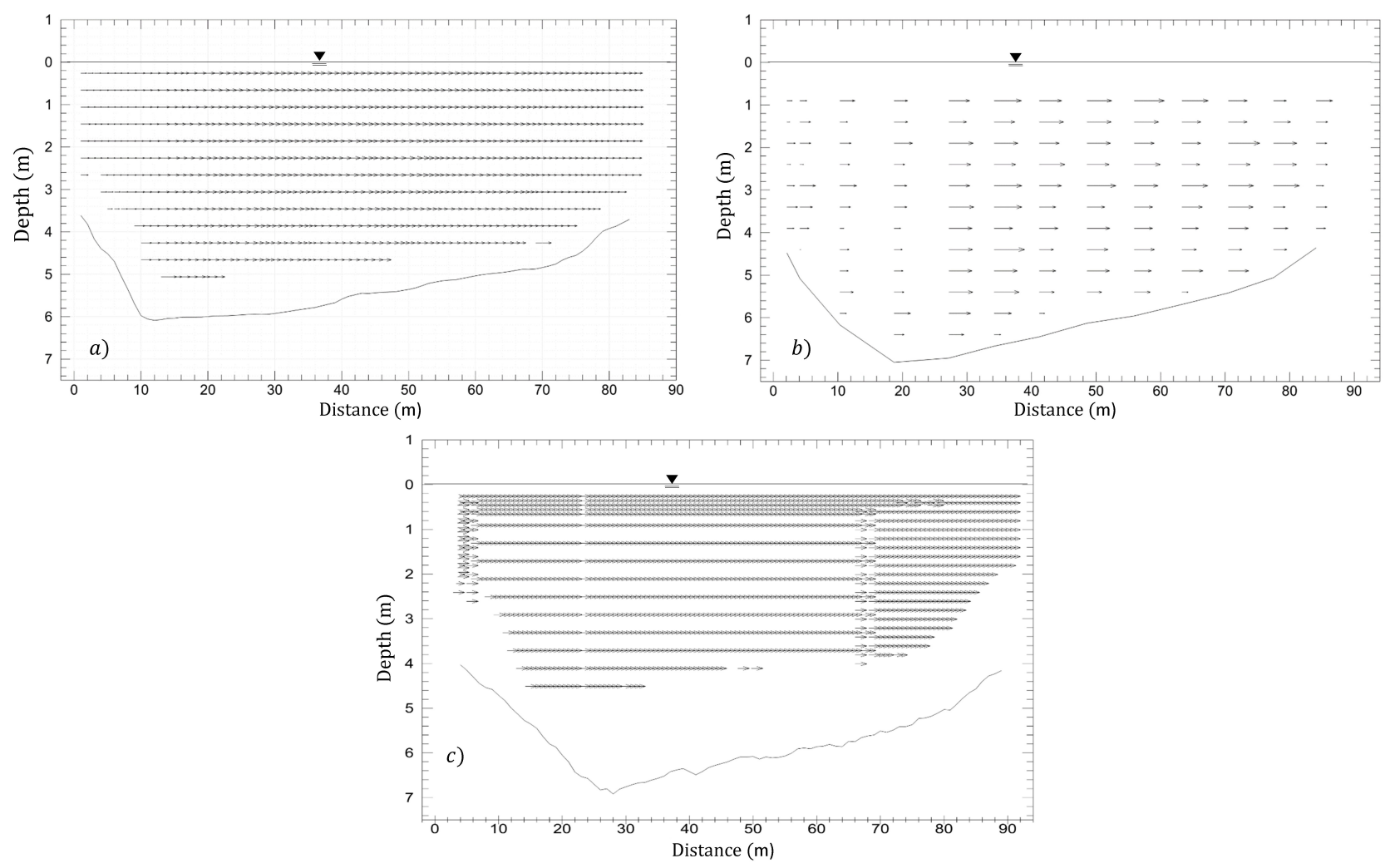

Figure 5. Velocity profiles in the cross section under study: a) $2000 \mathrm{kHz} ;$ b) $1500 \mathrm{kHz}$ and c) $600 \mathrm{kHz}$.

equipment, where the wavelength is very small, with acoustic energy losses due to absorption of suspended sediments of the return beam, so that the signal can be lost or distorted at depths greater than $5 \mathrm{~m}$ on the other hand, profilers that work at low frequencies have more penetration power, which 
allows solving this limitation. An additional advantage of using an ADCP, when compared to measurements made with mechanical current meters, is the measurement time (Muste and Spasojevic 2004). For a mechanical current meters, about one or two hours are needed to perform the measurements, while with an ADCP the process takes an average of 15 minutes. The only disadvantage that ADCPs have, in addition to their cost, is that their use is complicated and the operator must be trained in its configuration, measurement techniques and data processing.

\section{CONCLUSIONS}

Comparisons among the 2 000-, 1 500- and
$600-\mathrm{kHz}$ ADCPs show that choosing the correct frequency is essential for selecting the measurement equipment. For flow discharges, any frequency is useful, as long as the equipment is in its operating range; however, to describe the structure of the flow, the best ADCPs are those that work at high frequencies, such as the $2000-\mathrm{kHz}$ device, taking into account that the higher the frequency the lower the penetration power in the water column.

\section{ACKNOWLEDGEMENTS}

This research was conducted with the support of Basic Sciences project CB-2011-1660168, funded by CONACYT.

\section{LITERATURE CITED}

Arega F (2013) Hydrodynamic modeling and characterizing of Lagrangian flows in the West Scott Creek wetlands system, South Carolina. Journal of Hydro-environment Research 7: 50-60.

Baranya S, Olsen NRB, Józsa J (2015) Flow analysis of a river confluence with field measurements and RANS model with nested grid approach. River Research and Applications 31: 28-41.

BGS (2015) World Magnetic Model 2015 Calculator. http://www.geomag.bgs.ac.uk/data_service/models compass/wmm_calc.html. Date consulted: January 1, 2016.

Chang NB, Crawford AJ, Mohiuddin G, Kaplan J (2015) Low flow regime measurements with an automatic pulse tracer velocimeter (APTV) in heterogeneous aquatic environments. Flow Measurement and Instrumentation 42: 98-112.

Cundy AB, Lafite R, Taylor JA, Hopkinson L, Deloffre J, Charman R, et al. (2007) Sediment transfer and accumulation in two contrasting salt marsh/mudflat systems: the Seine estuary (France) and the Medway estuary (UK). Hydrobiologia 588: 125-134.

Fulford JM, Sauer VB (1986) Comparison of velocity interpolation methods for computing open-channel discharge. In: Geldon ALSY (ed.) Selected papers in the hydrologic sciences: U.S. Geological Survey Water-Supply Paper 2288. Colorado, United States. pp: 139-144.

García-Reyes M, Priego-Hernández G, Soto-Cortes G, Rivera-Trejo F (2017) Análisis hidrodinámico en un canal de derivación: caso el Censo, municipio de Centro, Tabasco. Journal of Energy, Engineering Optimization and Sustainability 1: 23-42.

Latosinski FG, Szupiany RN, García CM, Guerrero M, Amsler ML (2014) Estimation of concentration and load of suspended bed sediment in a large river by means of acoustic Doppler technology. Journal of Hydraulic Engineering 140(7). Doi: 10.1061/(ASCE)HY.1943-7900.0000859.

Mueller DS (2002) Field assessment of acoustic Doppler based discharge measurements. Proceedings, Hydraulic Measurements and Experimental Methods 2002, ASCE, Reston, Va. CD-ROM 
Mueller DS, Wagner CR, Rehmel MS, Oberg KA, Rainville F (2009) Measuring discharge with acoustic Doppler current profilers from a moving boat. US Department of the Interior, US Geological Survey. $72 \mathrm{p}$.

Muste M, Yu K, Spasojevic M (2004) Practical aspects of ADCP data use for quantification of mean river flow characteristics; Part I: moving-vessel measurements. Flow measurement and instrumentation, 15: 1-16.

Pérez AK, Díaz FF (2000) Manual de aforos. Instituto Mexicano de Tecnología del Agua. Morelos, México. $137 p$.

Priego-Hernandez G, Rivera-Trejo F (2016) Secondary currents: Measurement and analysis. Atmósfera 29: 23-34.

Rennie CD, Millar RG, Church MA (2002) Measurement of bed load velocity using an acoustic Doppler current profiler. Journal of Hydraulic Engineering 128: 473-483.

Riley JD, Rhoads BL (2011) Flow structure and channel morphology at a natural confluent meander bend. Geomorphology. Doi: 10.1016/j.geomorph.2011.06.011.

Rivera-Trejo F, Soto-Cortés G, Méndez-Antonio B (2010) The 2007 flood in Tabasco, Mexico: an integral analysis of a devastating phenomenon. International Journal of River Basin Management 8: 255-267.

Simpson MR (2001) Discharge measurement using an acoustic Doppler current profiler: U.S. Geological Survey Water-Supply Paper 8016-20, Virginia, United States. 40p.

Sontek (2007) RiverSurveyor System Manual Software Version 4.60: Son-Tek/YSI Inc, Manual, California, United Sates. 182p.

Szupiany RN, Amsler ML, Best JL, Parsons DR (2007) Comparison of fixed- and moving-vessel flow measurements with an aDp in a large river. Journal of Hydraulic Engineering 133: 1299-1309.

Szupiany RN, Amsler ML, Parsons DR, Best JL (2009) Morphology, flow structure, and suspended bed sediment transport at two large braid-bar confluences. Water Resources Research 45 W05415. Doi:10.1029/ 2008WR007428.

Teledyne RD Instruments (2014) WinRiver II Software User's Guide: P/N 957-6231-00, Manual, California, United Sates. 298p.

Venditti JG, Church M, Attard ME, Haught D (2016) Use of ADCPs for suspended sediment transport monitoring: An empirical approach. Water Resources Research 52: 2715-2736.

Vogt RH,Neubauer WG (1976) Relationship between acoustic reflection and vibrational modes of elastic spheres. The Journal of the Acoustical Society of America 60: 15-22.

Winterwerp JC, Wang ZB, Van der Kaaij T, Verelst K, Bijlsma A, Meersschaut Y, et al. (2006) Flow velocity profiles in the Lower Scheldt estuary. Ocean Dynamics 56: 284-294. 
